Tersedia Secara Online di

\title{
Studi Perencanaan Perkerasan Lentur Dan Rencana Anggaran Biaya (Pada Proyek Ruas Jalan Karangtalun - Kalidawir Kabupaten Tulungagung)
}

\author{
H. Prasetiyo ${ }^{1 *}$, Y.C. S. Poernomo ${ }^{2}$, A. I. Candra ${ }^{3}$. \\ ${ }^{1 * 2,3}$ Fakultas Teknik. Universitas Kadiri. \\ email: ${ }^{1 *}$ denmashenny@gmail.com
}

\begin{tabular}{ll} 
A R T I C L E & I N F O \\
\hline Article history: & \\
Artikel masuk & $: 19-10-2020$ \\
Artikel revisi & $: 22-10-2020$ \\
Artikel diterima & $: 24-10-2020$ \\
\hline
\end{tabular}

Keywords :

Geometric, Flexible Pavement, RAB, 2017 Design Manual Method

\footnotetext{
Style IEEE dalam mensitasi artikel ini:

[10]

A. Andriansyah, P. Pratomo, and $H$. Ali, "Optimalisasi Tebal Perkerasan Pada Pekerjaan Pelebaran Jalan dengan Metode MDPJ 02/M/BM/2013 dan Pt T-012002-B,” J. Rekayasa Sipil dan Desain, vol. 4, no. 1, pp. 113-126, 2016.
}

\begin{abstract}
A B S TRA C T
Road pavement is a major component in supporting the smooth running of land transportation so that it can be accessed comfortably and safely by road users. Road pavement, according to its type, is divided into three types, namely flexible pavement, rigid pavement, and composite pavement. On flexible pavements, there are several methods used to determine the thickness of the pavement in the initial plan. The method used as a reference is the 2017 Design Manual Method, and the calculation of the RAB refers to the Basic Unit Price Analysis in 2019. This study aims to obtain good quality flexible pavement but at a low cost in terms of the 2017 Design Manual method and analysis calculations and The price of the basic unit (RAB) in 2019. From the calculation of the pavement thickness of each layer, namely the top layer of $5 \mathrm{~cm}$, the middle layer of $20 \mathrm{~cm}$, and the bottom layer of $15 \mathrm{~cm}$, it is known that the cost required to carry out the construction of the pavement is Rp. 73,342,707,500.00.
\end{abstract}


dan lapis bawah $15 \mathrm{~cm}$ diketahui biaya yang diperlukan guna melaksanakan pembangunan perkerasan jalan tersebut sebesar Rp. 73.342.707.500,00.

\section{Pendahuluan}

Perkerasan adalah sebuah upaya yang utama guna menunjang lancarnya sistem transportasi secara baik dan sesuai dengan keinginan [1]. Oleh karena itu dibutuhkan perkerasan jalan yang memadai dan layak untuk dipergunakan [2]. Perkerasan jalan menurut jenisnya dibagi menjadi tiga yaitu perkerasan lentur, perkerasan kaku dan perkerasan komposit [3]. Perkerasan lentur adalah metode lapis perkerasan, dimana apsal merupakan bahan pengikat dari bahan penyusunnya seperti koral, pasir dan filler, serta memiliki sifat menyebar rata beban yang diterima dari kendaraan kepondasi bawah, yang mengacu pada Metode Manual Desain 2017 [4]. Setelah dicari tebal perkerasan lentur kemudian di Analisa berapa anggaran yang dibutuhkan dalam perencanaan tersebut [5]. Dengan mengacu pada perhitungan RAB Analisa Harga Satuan Dasar pada tahun 2019 [6].

Setiap tahunnya pada kondisi ruas jalan Karangtalun-Kalidawir ini semakin menurun kualitasnya, sehingga menyebabkan pengendara dan masyarakat disekitar kurang nyaman dan berbahaya apalagi musim hujan tiba sering terjadi kecelakaan karena banyak lubang pada ruas jalan Karangtalun-Kalidawir [7]. Dari penjelasan diatas maka dilakukan studi perencanaan ulang tebal lapis dan lebar perkerasan lentur dengan Metode Manual Desain Perkerasan 2017 [8]. Karena terlihat perlu adanya sebuah perencanaan perkerasan lentur pada Ruas Jalan Karangtalun - Kalidawir Kabupaten Tulungagung, mengingat ruas jalan tersebut merupakan jalan penghubung anatra kecamatan dengan kota [9].

\section{Studi Literatur}

\subsection{Studi Terdahulu}

Adapun studi terdahulu yang dijadikan penulis sebagai referensi terkait penelitian adalah penelitian yang dilakukan oleh Andriansyah et al. pada tahun 2016, yang mengangkat judul "Study Pekerjaan Pelebaran Jalan dengan Metode MDPJ 02/M/BM/2013 dan Pt T-012002-B ditinjau dari Tebal Lapis Perkerasan Jalan" [10]. Hal yang dapat disimpulkan dari penelitian ini adalah bahwa tebal lapis permukaan $20 \mathrm{~cm}$, tebal lapis pondasi $15 \mathrm{~cm}$ dan tebal lapis pondasi bawah $15 \mathrm{~cm}$ serta RAB sebesar Rp. 32.643.124.163,76.

\footnotetext{
Studi Perencanaan Perkerasan Lentur Dan Rencana Anggaran Biaya (Pada Proyek Ruas Jalan Karangtalun - Kalidawir Kabupaten 


\subsection{Jalan Raya}

Jalan merupakan sebuah sarana transportasi dara, dimana bagiannya meliputi semua bagian jalan termasuk bangunan yang melengkapi dari jalan itu serta dipergunakan bagi lalu lintas yang berada pada permukaan, atas, dan bawah permukaan tanah, serta di atas permukaan air, kecuali jalankereta api, jalan lori, dan jalan kabel [11] [12].

\subsection{Perkerasan Jalan}

Perkerasan jalan adalah sebuah bangunan yang terletak diatas lapisan tanah dasar (subgrade) berfungsi sebagai penopang beban lalu lintas [13]. Agar didapat hasil yang sesuai dengan mutu yang diharapkan maka pengetahuan tentang sifat, pengadaan dan pengelolahan dari bahan penyusun perkerasan jalan sangat diperlukan [14].

Konstruksi perkerasan tersusun atas beberapa jenis lapisan berdasarkan bahan penyusunnya yang meliputi [15]:

\section{Konstruksi Perkerasan Lentur (Flexibel Pavement)}

Merupakan sebuah jenis perkerasan dimana bahan pengikatnya menggunakan aspal, lapisan-lapisan perkerasannya bersifat memikul dan menyebarkan bahan lalu lintas ke tanah dasar[16].

2. Konstruksi Perkerasan Kaku (Rigid Pavement)

Merupakan sebuah lapis perkerasan yang menggunakan semen sebagai bahan pengikat.

Plat beton dengan atau tanpa tulangan diletakkan diatas tanah dasar dengan atau tanpa lapis pondasi bawah[17].

\section{Konstruksi Perkerasan Komposit (Composit Pavement)}

Merupakan sebuah lapis perkerasan kaku yang merupakan hasil kombinasi dengan perkerasan lentur[18].

Perbedaan utama antara perkerasan kaku dan perkerasan lentur diberikan pada Tabel 1. seperti yang terlihat di bawah ini [19]: 
Tabel 1. Perbedaan Lapis Perkerasan Lentur Dengan Kaku.

\begin{tabular}{|c|c|c|c|}
\hline & & Perkerasan Lentur & Perkerasan kaku \\
\hline 1 & Instrumen Pengikat & Bitumen (Aspal) & Semen Protdland \\
\hline 2 & Beban Over & Terjadi lendutan & $\begin{array}{l}\text { Munculnya keretakan pada lapis } \\
\text { jalan }\end{array}$ \\
\hline 3 & $\begin{array}{l}\text { Terjadi Penyusutan } \\
\text { Tanah Pondasi }\end{array}$ & $\begin{array}{l}\text { Lapis jalan bergelombang } \\
\text { (tidak rata) }\end{array}$ & $\begin{array}{l}\text { Menjadi tempat perletakan/balok } \\
\text { untuk lapis perkerasan }\end{array}$ \\
\hline 4 & $\begin{array}{l}\text { Adanya Perubahan } \\
\text { Suhu Eksrim }\end{array}$ & $\begin{array}{l}\text { Munculnya Tegangan dalam } \\
\text { kecil karena adanya } \\
\text { perubahan kekakuan } \\
\text { modulus. }\end{array}$ & $\begin{array}{l}\text { Muncul tegangan dalam besar } \\
\text { namun kekakuan modulus tetap. }\end{array}$ \\
\hline
\end{tabular}

Sumber : Sukirman,Silvia.1999. Perkerasan Lentur Jalan Raya.Bandung. NOVA.

\subsection{Umur Rencana}

Umur rencana adalah hasil penjumlahan dari tahun pada awal jalan dibuka pertama kali sebagai lalu lintas kendaraan hingga diperlukan adanya suatu perbaikan yang bersifat struktural (sampai diperlukan penambahan lapis perkerasan) [20]. Dalam umur rencana, pemeliharaan pada perkerasan jalan harus tetap dilaksanakan, pada lapisan nonstruktural yang difungsikan sebagai lapisan atas [21]. Pada umur rencana perkerasan lentur guna jalan baru biasanya diambil 20 tahun serta peningkatan 10 tahun [22]. Berikut cara penentuan kapasitas pada kondisi lapangan:

$\mathrm{C}$

$$
=\mathrm{C}_{\mathrm{o}} \mathrm{x} \mathrm{FC}_{\mathrm{w}} \times \mathrm{FC}_{\mathrm{SP}} \times \mathrm{FC}_{\mathrm{SF}}
$$

Keterangan:

$\mathrm{C}=$ Kapasitas $(\mathrm{smp} / \mathrm{jam})$

$\mathrm{C}_{\mathrm{o}} \quad=$ Kapasitas dasar $(\mathrm{smp} / \mathrm{jam})$

$\mathrm{FC}_{\mathrm{w}} \quad=$ Faktor penyesuaian lajur lalu lintas

$\mathrm{FC}_{\mathrm{SP}} \quad=$ Faktor penyesuaian arah lalu lintas

$\mathrm{FC}_{\mathrm{SF}} \quad=$ Faktor penyesuaian gesekan samping

Menentukan kapasitas jalan dengan 2 lajur 2 arah tak terbagi, lebar jalan 5,50meter dan bahu jalan 1,00 meter.

Co $\quad=3100 \mathrm{smp} / \mathrm{jam} / \mathrm{lajur}$ (Jenis dan alinyemen jalan datar, Tipe jalan dua lajur dua arah tak terbagi total dua arah)

FCW $\quad=0,80$ (Lebar jalur efektif 5,5 meter)

FCSP $=1,00$ (Dua lajur 2-2 pemisahan 50\%-50\%)

FCSF $\quad=0,91$ (Hambatan samping dengan lebar 1,00 meter, kondisi tipikal Medium)

Umur rencana perkerasan baru dinyatakan pada Tabel 2.

Studi Perencanaan Perkerasan Lentur Dan Rencana Anggaran Biaya (Pada Proyek Ruas Jalan Karangtalun - Kalidawir Kabupaten 
Tabel 2. Umur Rencana Perkerasan Jalan Baru (UR).

\begin{tabular}{|c|c|c|}
\hline Jenis Perkerasan & Elemen Perkerasan & $\begin{array}{l}\text { Umur Rencana } \\
\text { (tahun) }^{(1)}\end{array}$ \\
\hline \multirow{4}{*}{ Perkerasan lentur } & Lapisan aspal dan lapisan berbutir ${ }^{(2)}$. & 20 \\
\hline & Fondasi jalan & \\
\hline & $\begin{array}{l}\text { Semua perkerasan untuk daerah yang tidak } \\
\text { dimungkinkan pelapisan ulang (overlay), seperti: } \\
\text { jalan perkotaan,underpass, jembatan, terowongan. }\end{array}$ & 40 \\
\hline & Cement TreatedBased (CTB) & \\
\hline Perkerasan kaku & $\begin{array}{l}\text { Lapis fondasi atas, lapis fondasi bawah, lapis beton } \\
\text { semen, dan fondasi jalan. }\end{array}$ & \\
\hline $\begin{array}{l}\text { Jalan tanpa } \\
\text { penutup }\end{array}$ & Semua elemen (termasuk fondasi jalan) & Minimum 10 \\
\hline
\end{tabular}

\subsection{Regional Factor (FR)}

Regional Factor disebut juga sebagai faktor koreksi yang berhubungan pada perbedaan kondisi [23]. Kondisi ini antara lain seperti faktor lapangan serta iklim yang mampu mempengaruhi keadaan perbedaan daya dukung tanah dan perkerasan [24]. Dalam penentuan tebal perkerasan ini faktor regional hanya dipengaruhi oleh bentuk alinemen (kelandaian dan tikungan) [25]. Pada Tabel 3. disajikan prosentase kendaraan berat dan yang berhenti serta iklim (curah hujan).

Tabel 3. Prosentase kendaraan berat dan yang berhenti serta Iklim (Curah Hujan).
$(<6 \%)$
$(6-10 \%)$
(>10\%)

\begin{tabular}{|c|c|c|c|c|c|c|}
\hline & $\leq 31 \%$ & $>31 \%$ & $\leq 31 \%$ & $>31 \%$ & $\leq 31 \%$ & $>31 \%$ \\
\hline $\begin{array}{l}\text { Keadaan I < } \\
950 \mathrm{~mm} / \mathrm{thn}\end{array}$ & 0,7 & $1,3-1,8$ & 1,2 & $1,7-2,2$ & 1,7 & $2,2-2,7$ \\
\hline $\begin{array}{l}\text { Keadaan II } \geq \\
950 \mathrm{~mm} / \mathrm{thn}\end{array}$ & 1,7 & $2,2-2,7$ & 2,2 & $2,7-3,2$ & 2,7 & $3,2-3,7$ \\
\hline \multicolumn{7}{|c|}{ Sumber : Data SKBI 2.3.26.1987. } \\
\hline \multicolumn{7}{|c|}{$\begin{array}{l}\text { Studi Perencanaan Perkerasan Lentur Dan Rencana Anggaran Biaya (Pada Proyek Ruas Jalan Karangtalun - Kalidawir Kabupate } \\
\text { Tulungagung) } \\
\text { http:/ / dx.doi.org/ 10.30737/jurmateks }\end{array}$} \\
\hline
\end{tabular}




\subsection{Koefisien Distribusi Kendaraan}

Secara umum diperuntukan untuk kendaraan ringan dan berat yang lewat pada jalan rencana seperti terlihat pada Tabel 4. [26]:

Tabel 4. Koefisien Distribusi Kendaraan.

\begin{tabular}{ccccc}
\hline & \multicolumn{2}{c}{ Kendaraan ringan *) } & \multicolumn{2}{c}{ Kendaraan berat **) } \\
Jumlah jalur & 1 arah & 2 arah & 1 arah & 2 arah \\
\cline { 2 - 5 } & 0,95 & 0,95 & 0,95 & 0,95 \\
\hline 1 lajur & 0,55 & 0,49 & 0,69 & 0,49 \\
2 lajur & 0,39 & 0,39 & 0,45 & 0,469 \\
3 lajur & - & 0,25 & - & 0,46 \\
4 lajur & - & 0,25 & - & 0,43 \\
5 lajur & - & 0,20 & - & 0,39 \\
6 lajur & & & & \\
\hline
\end{tabular}

Sumber : Data SKBI 2.3.26.1987.

\subsection{Rencana Anggaran Biaya (RAB)}

Untuk menentukan besarnya biaya yang diperlukan terlebih dahulu harus diketahui volume dari pekerjaan yang direncanakan [27]. Pada umumnya pembuat jalan tidak lepas dari masalah galian maupun timbunan. Besarnya galian dan timbunan yang akan dibuat dapat dilihat pada gambar long profile. Sedangkan volume galian dapat dilihat melalui gambar cross section.

\section{Metodologi Penelitian}

Teknik pengumpulan data yang biasa dilakukan peneliti adalah mencari data primer dan data sekunder [28]. Data-data yang digunakan dalam studi perencanaan ini adalah data sekunder. Data sekunder merupakan data arsip yang didapat dari perusahaan atau kontraktor serta dari instansi terkait. Data tersebut anatara lain:

a. Data Lalulintas Harian Rata-rata

Data Lalu lintas Harian Rata-rata tahun 2019 dari Consultan Hirfi Studio dinaungi oleh kantor Dinas Pekerjaan Umum Bina Marga Kabupaten Tulungagung.

Studi Perencanaan Perkerasan Lentur Dan Rencana Anggaran Biaya (Pada Proyek Ruas Jalan Karangtalun - Kalidawir Kabupaten 
b. Data Tanah

Data pengujian tanah guna memperoleh nilai CBR tanah dasar, dimana nilai itu digunakan guna menentukan tingkat ketebalan perkerasan yang dilaksanakan dengan interval 200 meter diperoleh dari Consultan Hirfi Studio dimana semua pekerjaan itu dibawah kendali DPU Bina Marga Kabupaten Tulungagung setempat [29].

c. Data Gambar Jalan

Data gambar rencana jalan didapat dari Consultan Hirfi Studio dibawah kendali DPU Bina Marga Kabupaten Tulungagung setempat.

d. Data Harga Satuan Bahan, Upah dan Peralatan

Data Harga Satuan Bahan, Upah dan Peralatan tahun 2019 dari kantor Dinas Pekerjaan Umum Bina Marga Kabupaten Tulungagung.

Perhitungan RAB ini meliputi juga dalam menentukan nilai volume pekerjaan, analisa biaya serta RAB yang mengacu terhadap Peraturan Menteri (PerMen) PU serta Perumahan Rakyat Republik Indonesia No. 28/PRT/M/2016 tentang Pedoman Analisis Harga Satuan Pekerjaan Bidang Pekerjaan Umum [30].

\section{Hasil dan Pembahasan}

\subsection{Analisis Data BCWS, BCWP, dan ACWP}

Dalam menetapkan Kriteria Jalan mengacu pada Peraturan Menteri Pekerjaan Umum Nomor 19/PRT/M/2011 tentang persyaratan teknis jalan dan kriteria perencanaan teknis jalan.

Fungsi Jalan

Status Jalan

Kelas Jalan

Type Jalan

Lebar Lajur Lalulintas

Kemiringan Perkerasan Jalan

Kemiringan Bahu Jalan

Umur Rencana
$=$ Jalan Lokal

= Jalan Kabupaten

$=$ Kelas III

$=1$ jalur, 2 lajur 2 arah

$=2 \times 2,75$ meter

$=2 \%$ (Lamp. Permen PU no.19)

$=4 \%$ (Lamp. Permen PU no.19)

$=10$ tahun 


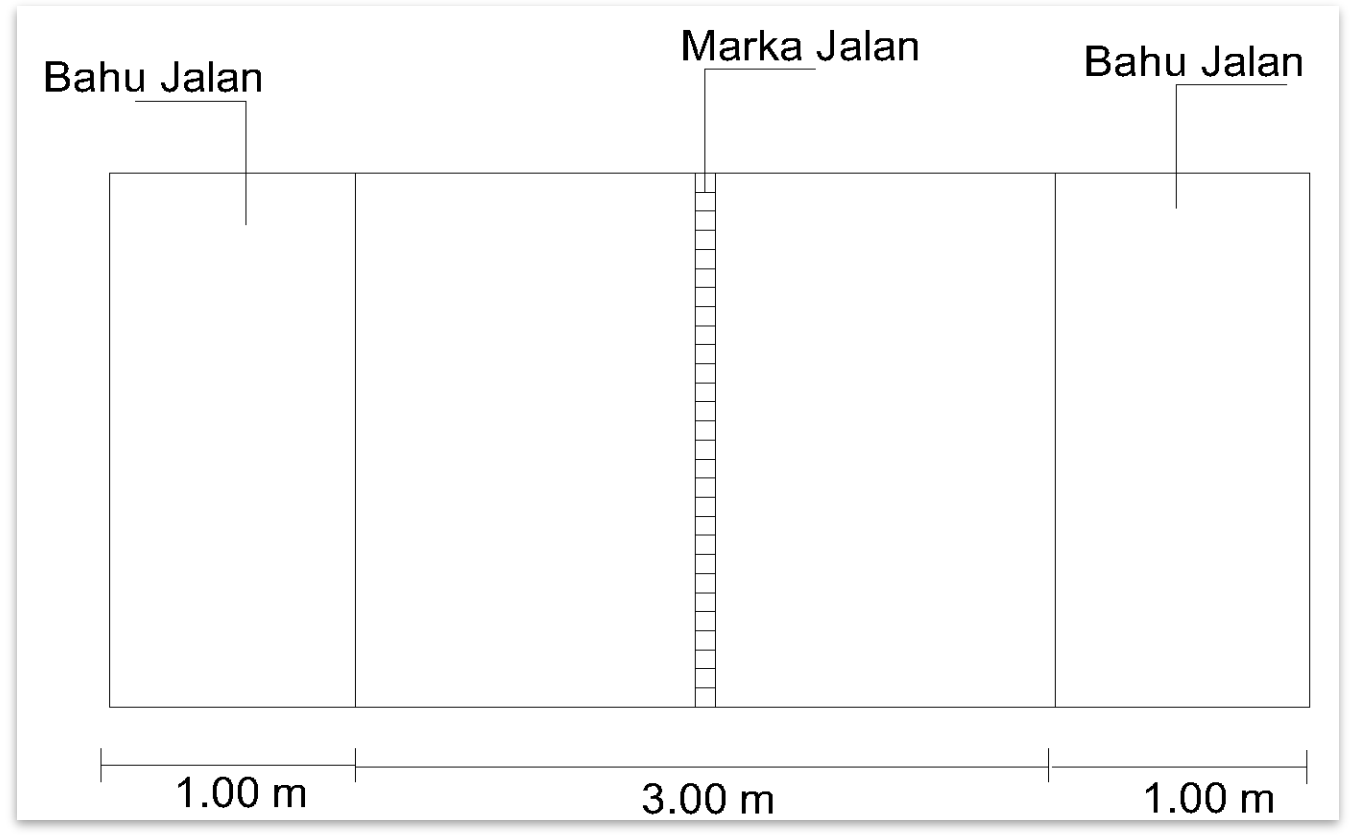

Sumber : Denah Jalan Lama, digambar melalui AutoCAD.

Gambar 1. Denah Jalan Lama.

Pada Gambar 1. ini terlihat denah jalan lama, dimana terlihat bahwa ada dua lajur dengan lebar $3 \mathrm{~m}$. serta bahu jalan $1 \mathrm{~m}$ di setiap sisi.

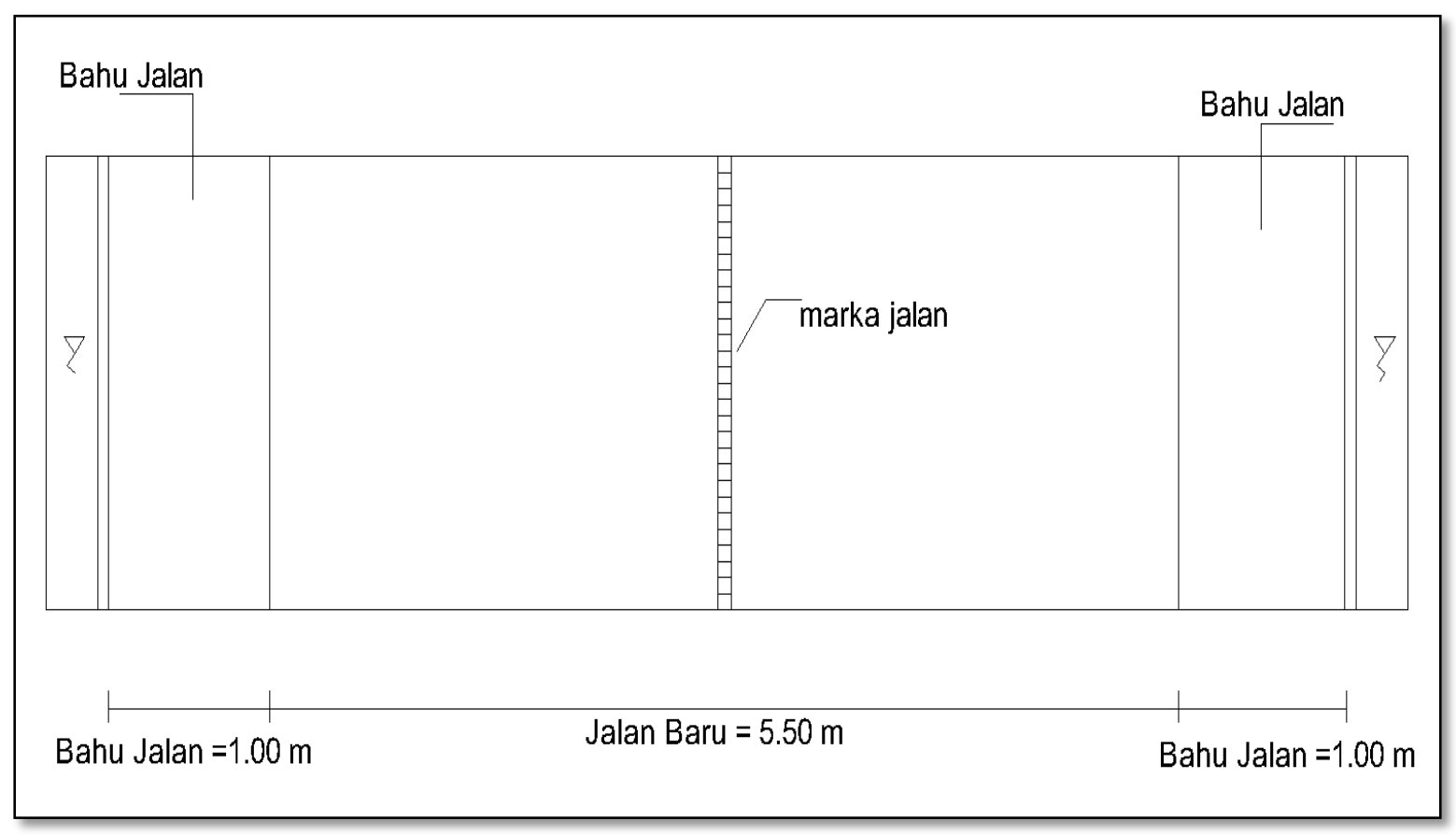

Sumber : Denah Jalan Baru, digambar melalui AutoCAD.

Gambar 2. Denah Jalan Baru.

Pada Gambar 2. terlihat denah jalan baru, terlihat terdapat penambahan lebar lajur menjadi 5,5 m.

Studi Perencanaan Perkerasan Lentur Dan Rencana Anggaran Biaya (Pada Proyek Ruas Jalan Karangtalun - Kalidawir Kabupaten Tulungagung) 


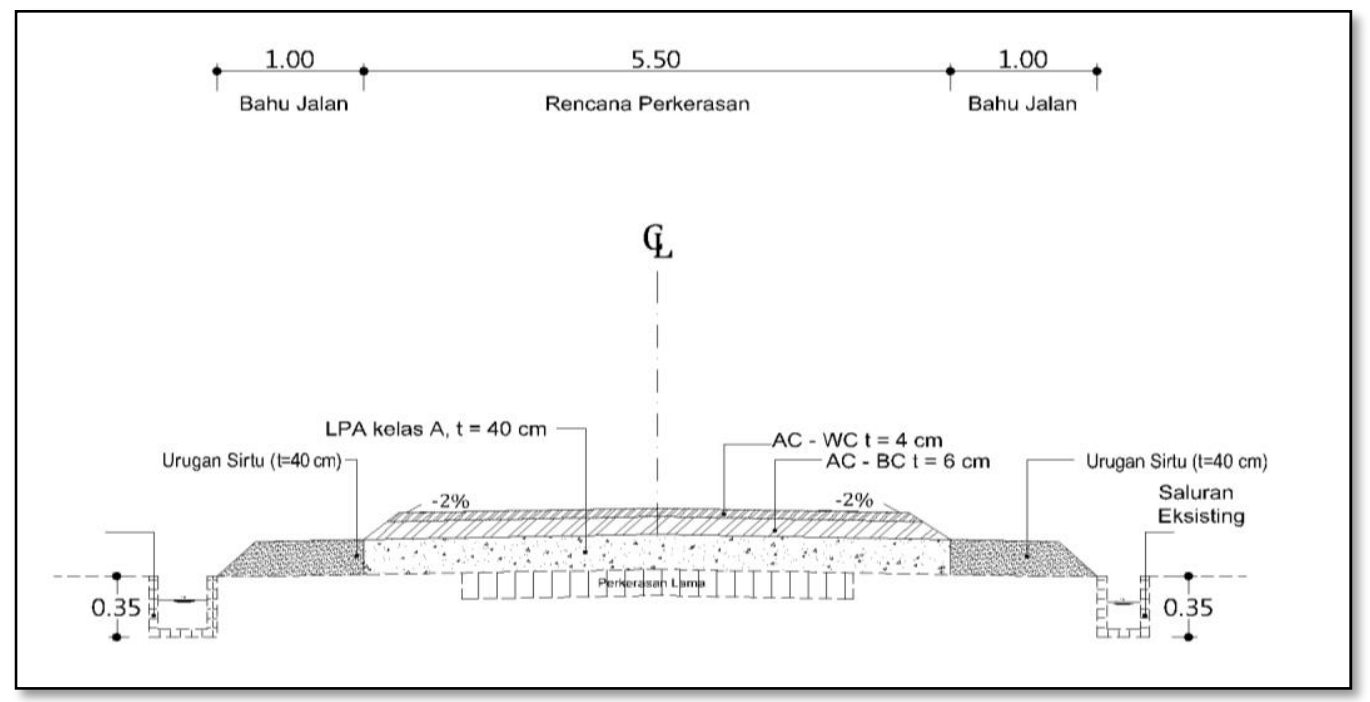

Sumber : Potongan Melintang Jalan Baru, digambar melalui AutoCAD.

Gambar 3. Potongan Melintang Jalan Baru.

Pada Gambar 3. terlihat denah lengkap perencanaan perkerasan jalan baru, sudah mencangkup semua ketentuan dalam perkerasan jalan raya dengan sistem 1 jalur 2 lajur.

\subsection{Umur Rencana}

Umur rencana perkerasan lentur digunakan elemen perkerasan lapis aspal dan lapisan berbutir yaitu 20 tahun yang terdapat pada tabel 3 Pada penentuan umur rencana tersebut harus memperhitungkan kapasitas jalan. Menurut MKJI 1997 kapasitas jalan didefinisikan sebagai arus maksimum melalui suatu titik di jalan yang dapat dipertahankan per satuan jam pada kondisi tertentu.

Tabel 5. Perhitungan Satuan Mobil Penumpang pada Lalu lintas Harian Rata-rata tahun 2019.

\begin{tabular}{|c|c|c|}
\hline Jenis Kendaraan & LHRT $_{2019}$ & EMP \\
\hline
\end{tabular}

1 Sepeda Motor

2 Mobil Penumpang / pick up

3 Truk 2 sumbu - ringan (8ton)
763

1,20

915,60

373

1,00

373,00

218

1,80

392,40

Jumlah

$\underline{1681,00}$

\section{Sumber : Data Perhitungan Satuan Mobil Penumpang pada LHR tahun 2019.}

Studi Perencanaan Perkerasan Lentur Dan Rencana Anggaran Biaya (Pada Proyek Ruas Jalan Karangtalun - Kalidawir Kabupaten 
Tabel 6. Perhitungan LHRT pada umur rencana 5TH, 10TH dan $20 \mathrm{TH}$.

\begin{tabular}{|c|c|c|c|c|c|c|c|c|}
\hline \multirow{3}{*}{ No } & \multirow{3}{*}{ Jenis Kendaraan } & \multirow{3}{*}{$\begin{array}{c}\text { LHRTi x } \\
\text { EMP } \\
\text { (smp / } \\
\text { jam) }\end{array}$} & \multicolumn{6}{|c|}{ Umur Rencana } \\
\hline & & & \multicolumn{2}{|c|}{$5 \mathrm{TH}$} & \multicolumn{2}{|c|}{$10 \mathrm{TH}$} & \multicolumn{2}{|c|}{$20 \mathrm{TH}$} \\
\hline & & & $\mathrm{R}$ & LHRT & $\mathrm{R}$ & LHRT & $\mathrm{R}$ & LHRT \\
\hline 1 & Sepeda Motor & 73,25 & 5,0071 & 89,06 & 10,032 & 173,17 & 20,136 & 2391,09 \\
\hline 2 & $\begin{array}{l}\text { Mobil Penumpang / } \\
\text { pick up }\end{array}$ & 29,84 & 5,0051 & 36,28 & 10,023 & 70,49 & 20,097 & 968,07 \\
\hline 3 & $\begin{array}{l}\text { Truk } 2 \text { sumbu - } \\
\text { ringan (8ton) }\end{array}$ & 31,39 & 5,0042 & 38,16 & 10,019 & 74,14 & 20,080 & 1015,74 \\
\hline & Jumlah & 134,48 & & $\underline{163,50}$ & & $\underline{317,80}$ & & $\underline{4374,90}$ \\
\hline
\end{tabular}

Sumber : Analisa Perhitungan LHRT pada umur rencana 5TH, 10TH dan 20TH.

Pada Tabel 5. dan Tabel 6. terlihat data lalu lintas harian pada umur rencana 5 tahun, 10 tahun, dan 20 tahun yaitu 163,50smp/jam, 317,80 smp/jam dan 4374,90 smp/jam sedangkan kapasitas jalan yang dapat melayani lalulintas sebesar $1681 \mathrm{smp} / \mathrm{jam}$. Untuk mengetahui umur rencana yang digunakan dapat dilihat dari Gambar 4.

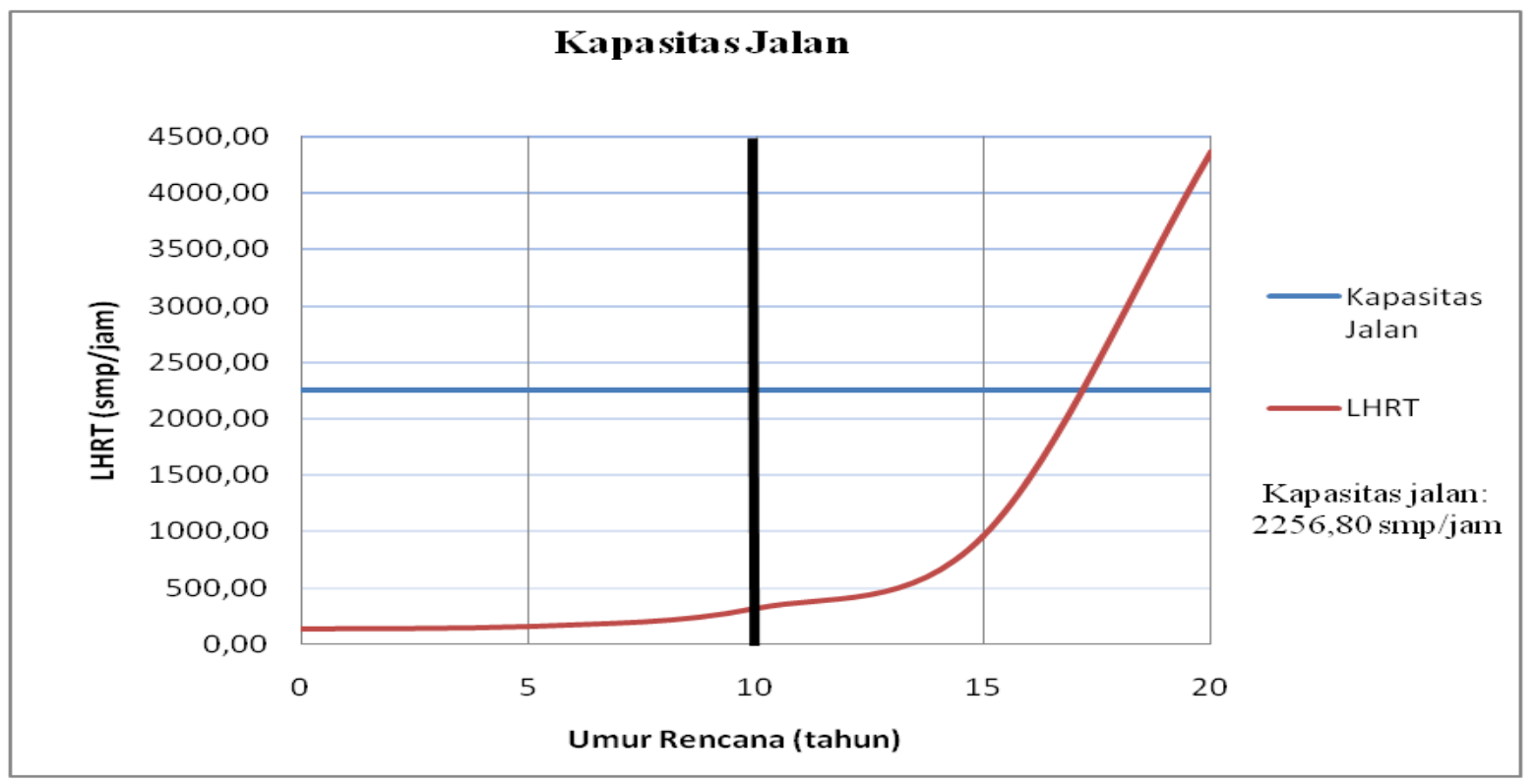

Sumber : Analisa Perhitungan Hubungan Kapasitas Jalan dengan Umur Rencana.

Gambar 4. Hubungan Kapasitas Jalan dengan Umur Rencana.

Jadi, umur rencana yang digunakan yaitu 10 tahun karena laulintas harian pada umur rencana 10 tahun tidak melebihi kapasitas jalan yang diperhitungkan.

Studi Perencanaan Perkerasan Lentur Dan Rencana Anggaran Biaya (Pada Proyek Ruas Jalan Karangtalun - Kalidawir Kabupaten 


\subsection{Analisa Perhitungan Harga}

a. Bobot Kerja

Perhitungan bobot pekerjaan dihitung dengan mengalihkan volume tiap pekerjaan dengan harga satuan tiap pekerjaan.

Bobot $\quad=$ Volume $\mathrm{x}$ Harga Satuan

Contoh perhitungan :

Bobot pekerjaan = Volume pekerjaan $\mathrm{x}$ harga satuan

$$
\begin{aligned}
& =5.000 .000 \times 1 \\
& =5.000 .000
\end{aligned}
$$

b. Persen (\%) Bobot Pekerjaan

Perhitungan persen $(\%)$ bobot pekerjaan dihitung dengan membandingkan bobot tiap pekerjaan dengan bobot total pekerjaan dikalikan $100 \%$.

$\%$ Bobot pekerjaan $=\frac{\text { Bobot pe ker jaan }}{\text { Bobot total }} \times 100 \%$

Contoh perhitungan :

$\%$ Bobot pekerjaan $=\frac{\text { Bobot peker jaan pengukuran }}{\text { Bobot total }} \times 100 \%$

$$
\begin{aligned}
& =\frac{5 \cdot 000.000}{10.000 .000 .000} \times 100 \% \\
& =0,05 \%
\end{aligned}
$$

\subsection{Volume Pekerjaan}

Perhitungan volume pekerjaan perkerasan lentur dapat dihitung sebagai berikut :

a. Pekerjaan Pendahuluan

Pekerjaan Pembongkaran Jalan Lama

Volume $=$ Panjang jalan $\mathrm{x}$ lebar bahu jalan

$$
=1145 \times 2=2290 \mathrm{~m} 2
$$

b. Pekerjaan Perkerasan

\section{Lapis Pondasi Atas}

Lapisan pondasi atas = Panjang lapis pondasi dengan ketebalan sama $\mathrm{x}$ lebar jalan $\mathrm{x}$ tebal

$$
=1145 \times 2,5 \times 0,4=1145 \mathrm{~m} 3
$$


c. Lapis permukaan (Laston)

Lapis resap pengikat:

Lapis pengikat $=\mathrm{A}$ (luas jalan $\mathrm{x}$ panjang jalan) $\mathrm{x}$ takaran penyemprotan lapis pengikat pada pembukaan jalan baru(Takaran lapis pngikat adalah 0,8 liter/m2).

Lapis pengikat $=(5,5 \times 1145) \times 0,8$ liter $/ \mathrm{m}^{2}$

$=5038$ liter

Lapis Perekat

Lapis Perekat = A (luas permukaan) $\mathrm{x}$ takaran penyemprotan lapis perekat pada pembukaan jalan baru(Takaran lapis pngikat adalah 0,4 liter/m2).

Lapis perekat $=(5,5 \times 1145) \times 0,4$ liter $/ \mathrm{m} 2$

$=2519$ liter

Laston AC-WC

Laston

= panjang jalan $\mathrm{x}$ Lebar jalan $\mathrm{x}$ Tebal jalan $\mathrm{x}$ Berat isi laston AC-WC $=1145 \times 5,5 \times 0,04 \times 2,35=591,965$ ton

Laston AC-BC

Laston $\quad=$ panjang jalan $\mathrm{x}$ Lebar jalan $\mathrm{x}$ Tebal jalan $\mathrm{x}$ Berat isi laston $\mathrm{AC}-\mathrm{BC}$ $=1145 \times 5,5 \times 0,06 \times 2,34=884,169$ ton

d. Pekerjaan bahu jalan

Pekerjaan bahu jalan = Panjang jalan $\mathrm{x}(1 / 2 \mathrm{x}$ lebar bahu $\mathrm{x}$ tebal bahu $) \times 2$ (kiri kanan)

$$
=1145 \times(1 / 2 \times 1 \times 0,4) \times 2=916 \mathrm{~m}^{3}
$$

Tabel 7. Rekapitulasi Anggaran Biaya.

Bab I: Umum

$27.500 .000,00$

Bab II: Pekerjaan Tanah

39.470.726.730,79

Bab III : Pekerjaan Lapis AC-WC Dan BC

17.543.968.157,09

Bab IV : Pekerjaan Lapis Perekat

7.971.355.170,87

Bab V : Pekerjaan Bahu Jalan

$134.353 .477,11$

JUMLAH

$66.675 .188 .567,37$

PPn 10\%

6.667.518.856,74

JUMLAH TOTAL

73.342.707.424,10

Dibulatkan $=(\mathrm{Rp}$.

73.342.707.500,00

\section{Sumber : Analisa Perhitungan Rekapitulasi Biaya.}

Pada Tabel 7. terlihat hasil rekapitulasi total yang dibutuhkan dalam pekerjaaan lapis lentur jalan karangtalun - kalidawir dengan total harga Rp. 73.342.707.500,00.

Studi Perencanaan Perkerasan Lentur Dan Rencana Anggaran Biaya (Pada Proyek Ruas Jalan Karangtalun - Kalidawir Kabupaten Tulungagung) 


\section{Kesimpulan dan Saran}

\subsection{Kesimpulan}

Dari hasil penelitian mengenai perencanaan perkerasan ruas jalan KarangtalunKalidawir menggunakan jenis perkerasan lentur berdasarkan Metode Manual Desain 2017 yang ada dengan :

1. Jenis bahan yang dipakai adalah :

Surface Course : AC-WC, Base Course : AC-BC, Sub Base Course : Sirtu (CBR 50\%)

Dengan perhitungan didapatkan dimensi dengan tebal dari masing-masing lapisan :

Surface Course : $5 \mathrm{~cm}$, Base Course : $20 \mathrm{~cm}$ Sub, Base Course : $15 \mathrm{~cm}$

2. Jadi lebar tambahan yang perlu direncanakan adalah 2 meter, atau dilebarkan 1 meter pada setiap lajurnya.

3. Perencanaan pada ruas jalan Karangtalun-Kalidawir memerlukan biaya untuk pembangunan sebesar Rp. 73.342.707.500,00 dan dikerjakan selama 1 tahun 1 bulan.

\subsection{Saran}

Perencanaan geometrik jaldiwaktu berikutnya sebaiknya didasarkan atas data hasil survey langsung di lapangan agar diperoleh perencanaan yang optimal. Perencanaan perkerasan jalan sebaiknya menggunakan data selengkap mungkin baik data lalu lintas maupun data lainnya agar pembangunan dapat berjalan dengan optimal. 


\section{Daftar Pustaka}

[1] X. Yang, Z. You, J. Hiller, and D. Watkins, "Sensitivity of flexible pavement design to Michigan's climatic inputs using pavement ME design," Int. J. Pavement Eng., vol. 18, no. 7, pp. 622-632, 2017.

[2] A. D. Limantara, S. W. Winarto, and S. W. Mudjanarko, "SISTEM PAKAR PEMILIHAN MODEL PERBAIKAN PERKERASAN LENTURBERDASARKAN INDEKS KONDISI PERKERASAN (PCI)," Pros. Semnastek, 2017.

[3] T. Alenezi, J. Norambuena-Contreras, A. Dawson, and A. Garcia, "A novel type cold mix pavement material made with calcium-alginate and aggregates," J. Clean. Prod., vol. 212, pp. 37-45, 2019, doi: 10.1016/j.jclepro.2018.11.297.

[4] A. I. Candra, S. W. Mudjanarko, and A. D. Limantara, "Manajemen Data Lalu Lintas Kendaraan Berbasis Sistem Internet Cerdas Kadiri," Semnastek, vol. 4, no. 2, pp. 1-2, 2017.

[5] C. Zhang, H. Wang, Z. You, and X. Yang, "Compaction characteristics of asphalt mixture with different gradation type through Superpave Gyratory Compaction and XRay CT Scanning," Constr. Build. Mater., vol. 129, pp. 243-255, 2016, doi: 10.1016/j.conbuildmat.2016.10.098.

[6] D. J. B. Marga, "Departemen Pekerjaan Umum," Man. Kapasitas Jalan Indones. (MKJI 1997), Jakarta, 1997.

[7] F. Russo, S. A. Biancardo, A. Formisano, and G. Dell'Acqua, "Predicting percent air voids content in compacted bituminous hot mixture specimens by varying the energy laboratory compaction and the bulk density assessment method," Constr. Build. Mater., vol. 164, pp. 508-524, 2018, doi: 10.1016/j.conbuildmat.2017.12.174.

[8] D. D. B. Marga, “Manual Kapasitas Jalan Indonesia (MKJI),” vol. 7802112, no. 264, 1997.

[9] S. 03-1737-1989, "Tata Cara Pelaksanaan Lapis Aspal Beton (Laston) untuk Jalan Raya," p. 16, 1989.

[10] A. Andriansyah, P. Pratomo, and H. Ali, "Optimalisasi Tebal Perkerasan Pada Pekerjaan Pelebaran Jalan dengan Metode MDPJ 02/M/BM/2013 dan Pt T-01-2002-B,” J. Rekayasa Sipil dan Desain, vol. 4, no. 1, pp. 113-126, 2016.

[11] D. P. U. SKBI-2.3. 26. 1987, UDC: 625.73 (02), "Petunjuk Perencanaan Komponen Tebal Perkerasan Lentur Jalan Raya Dengan Metode Analisa Jalan," Peratur. Perenc. Geom. Jalan Raya, no. 13, 1970.

[12] M. R. Mohd Hasan, J. E. Hiller, and Z. You, "Effects of mean annual temperature and mean annual precipitation on the performance of flexible pavement using ME design," Int. J. Pavement Eng., vol. 17, no. 7, pp. 647-658, 2016.

[13] A. Bill et al., "Development of knowledge tables and learning outcomes for an introductory course in transportation engineering," Transp. Res. Rec., vol. 2211, no. 1, pp. 27-35, 2011.

[14] Dinas Pekerjaan Umum Bina Marga, Tata Cara Perencanaan Geometrik Jalan Antar Kota. Jakarta, 1997.

Studi Perencanaan Perkerasan Lentur Dan Rencana Anggaran Biaya (Pada Proyek Ruas Jalan Karangtalun - Kalidawir Kabupaten 
[15] P. Li and J. He, "Geometric design safety estimation based on tire-road side friction," Transp. Res. Part C Emerg. Technol., vol. 63, pp. 114-125, 2016.

[16] B. Marga, "Perkerasan Aspal, Spesifikasi Umum Divisi VI Revisi 3.” Jakarta, 2010.

[17] K. D. Hall, D. X. Xiao, and K. C. P. Wang, "Calibration of the Mechanistic-Empirical Pavement Design Guidefor Flexible Pavement Design in Arkansas," Transp. Res. Rec., vol. 2226, no. 1, pp. 135-141, 2011.

[18] P. Pereira and J. Pais, "Main flexible pavement and mix design methods in Europe and challenges for the development of an European method," J. Traffic Transp. Eng. (English Ed., vol. 4, no. 4, pp. 316-346, 2017.

[19] E. Gardjito, "STUDY PERENCANAAN GEOMETRIK, PERKERASAN JALAN DAN PERENCANAAN ANGGARAN BIAYA PADA JALAN RAYA KALIDAWIR-Ds. NGUBALAN Kec. KALIDAWIR," UKaRsT, vol. 1, no. 2, p. 11, 2017.

[20] DEPARTEMEN PEKERJAAN UMUM, “Perencanaan Sistem Drainase Jalan,” 2006.

[21] C. Caliendo, "Local calibration and implementation of the mechanistic-empirical pavement design guide for flexible pavement design," J. Transp. Eng., vol. 138, no. 3, pp. 348-360, 2012.

[22] K. P. Umum and D. J. B. Marga, "Manual Desain Perkerasan Jalan," Nomor 02/M/BM/2013, 2013.

[23] P. Chakroborty and A. Das, Principles of transportation engineering. PHI Learning Pvt. Ltd., 2017.

[24] J. M. Lutin, F. ITE, and A. L. Kornhauser, "The revolutionary development of selfdriving vehicles and implications for the transportation engineering profession," Cell, vol. 215, pp. 630-4125, 2013.

[25] E. H. Fini, F. Awadallah, M. M. Parast, and T. Abu-Lebdeh, "The impact of projectbased learning on improving student learning outcomes of sustainability concepts in transportation engineering courses," Eur. J. Eng. Educ., vol. 43, no. 3, pp. 473-488, 2018.

[26] A. Badrujaman, "Perencanaan Geometrik Jalan dan Anggaran Biaya Ruas Jalan Cempaka-Wanaraja Kecamatan Garut Kota,” J. Konstr., vol. 14, no. 1, 2016.

[27] E. N. Barmpounakis, E. I. Vlahogianni, and J. C. Golias, "Unmanned Aerial Aircraft Systems for transportation engineering: Current practice and future challenges," Int. J. Transp. Sci. Technol., vol. 5, no. 3, pp. 111-122, 2016.

[28] A. C. Mujianto, L. C. A. R. Jonathan, and A. Suroso, "EFISIENSI BIAYA PEMBANGUNAN PROYEK JALAN SP RESAK PETUNG PADA PT BANGUN CIPTA KONTRAKTOR," EKONOMIA, vol. 5, no. 1, pp. 68-73, 2016.

[29] S. Sukarman, Beton Aspal Campuran Panas. Yayasan Obor Indonesia, 2003.

[30] I. Bachtiar, "Rencana dan estimate Real of Cost,” Jakarta Bumi Aksara, 1993.

Studi Perencanaan Perkerasan Lentur Dan Rencana Anggaran Biaya (Pada Proyek Ruas Jalan Karangtalun - Kalidawir Kabupaten 